\title{
The Use of Fish Assemblages as Reserve Effect Indicators for Small Mpas. A Case Study in Southern Spain (Strait of Gibraltar)
}

\author{
José Carlos García Gómez ${ }^{1,2}$, Juan Sempere Valverde ${ }^{1 *}$, Javier Pellón ${ }^{1,2,}$ Stefania Coppa ${ }^{3}$ and Free Espinosa ${ }^{1}$ \\ ${ }^{1}$ Laboratorio de Biología Marina, Facultad de Biología, Universidad de Sevilla, Spain \\ ${ }^{2}$ Área de Investigación Biológica I+D+i del Acuario de Sevilla, Spain \\ ${ }^{3}$ Consiglio Nazionale delle Ricerche - Istituto per lo studio degli Impatti Antropici e Sostenibilità in ambiente marino (CNR-IAS), Italy
}

Submission: August 30, 2019; Published: September 20, 2019

Corresponding author: : Juan Sempere Valverde, Laboratorio de Biología Marina, Facultad de Biología, Universidad de Sevilla, Seville, Spain

\begin{abstract}
Marine protected areas (MPAs) are considered a useful tool for marine biodiversity and ecosystems conservation and management. Nevertheless, concern has arisen about the negative effects experienced on marine reserves with low levels of protection. In terms of fish conservation, small MPAs cannot provide effective protection for highly mobile species but can serve as reserve for low-mobility fishes. Therefore, these species could serve as indicators for small MPAs effectivity assessment. In this study, rapid surveys on fish assemblages were carried out in a small (1.8km long, 0.8km wide) no-take/no-entry zone of El Estrecho Natural Park (Alboran Sea, Spain) and a directly adjacent non-protected zone. Species of commercial interest and showing homing behaviour were used as indicators of reserve effect. Species with homing behaviour and of commercial interest could be good indicators of small coastal MPAs effectivity. Nevertheless, fish abundance and community structure did not vary in composition between protected and unprotected areas, which could suggest low to no protection for fish species in El Estrecho Natural Park. Additionally, insufficient resources for effective enforcement have been reported for this MPA. Therefore, management and effective surveillance of this marine protected area should be properly implemented to make protection effective in the studied area.
\end{abstract}

Keywords: Fish Indicators; Reserve Effect; Illegal Fishing; Paper Parks; MPAs Enforcement

\section{Introduction}

The establishment of marine protected areas (MPAs) is a universal conservation tool and an ever-increasing trend [1,2]. The main objectives when establishing an MPA are to obtain a series of benefits from areas in which extractive activities have been prohibited. These benefits are known as the reserve effect [3]. One of those benefits is to increase fish biomass and stock inside the MPA and enhance the migration of the stock from protected zones to nearby areas $[4,5]$. When this occurs, the reserve effect generates a transition border between protected and unprotected areas in which fish abundance diminishes progressively [6]. This transition border can be used to monitor and evaluate MPA effectiveness, especially for big MPAs, where the reserve effect can be tested a larger scale [7].

The current trend in coastal areas is to designate small-sized MPAs, as a consistent network of these is effective in terms of regional biodiversity conservation, especially for non-mobile species [8-10]. Nevertheless, very small MPAs have been criticized because of their low area/perimeter ratio, so larvae and biomass export to nearby areas will be high and it will be less effective in terms of highly mobile fish conservation [11]. In any case, the optimal size will depend on the specific objectives of each MPA and the environmental, ecological and socioeconomic context of the area in which it is implemented [12]. When establishing MPAs, the determination of proper management, enforcement and longterm monitoring are essential $[13,14]$. But for the monitoring of fishes and other mobile species on small MPAs $(<10 \mathrm{~km})$, the quick assessment of the reserve effect can be seriously hindered, especially in ways accessible to managers $[15,16]$.

In this matter, some families of benthic and nektobenthic fishes, which show homing behaviour (i.e. Blenniidae, Gobiidae or Labridae), have been proposed in order to detect the reserve effect at small scales, as they may be intendedly or unintendedly extracted by recreational and commercial fishing $[17,18]$. On the other hand, low-mobility species of commercial interest could be 
also used to test protection effectiveness on small MPAs $[19,20]$. Finally, fish species with schooling behaviour tend to approach to divers and come up several times during samplings and they are not indicated for rapid assessment methods carried out by divers or snorkelers, which are commonly used on citizen science $[21,22]$.The present study aims to evaluate the effectiveness of a small MPA in terms of fish abundance. Secondarily, the effectiveness of the spatial patterns of fish assemblages at small spatial scales will be considered as a tool for the management of small MPAs, especially for families of benthic or nektobenthic fishes (species with homing behaviour) and for species of commercial interest.

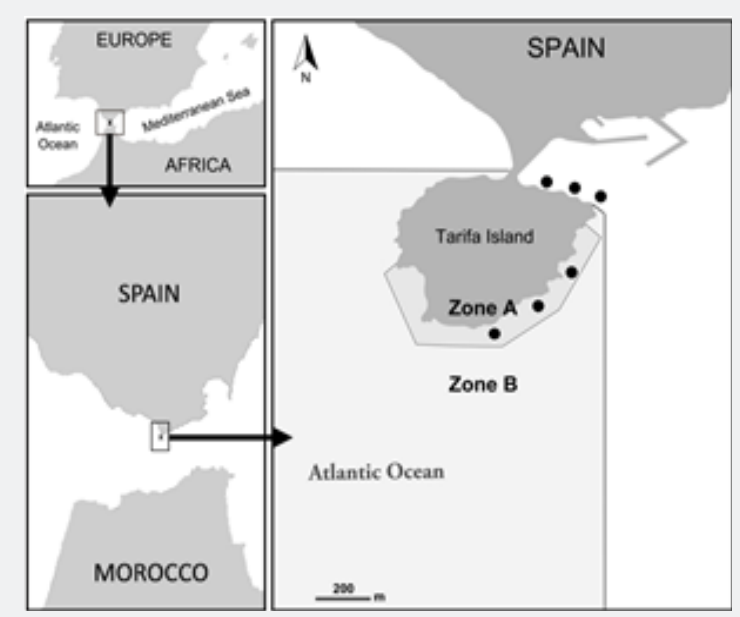

Figure 1: Location of the Marine Protected Area of El Estrecho Natural Park and location of the no-take/no-entry zone (Zone A) and medium protection zone (Zone B) in the proximities of Tarifa Island $\left(36^{\circ} 00^{\prime} 10.8^{\prime \prime} \mathrm{N} 5^{\circ} 36^{\prime} 35.8\right.$ 'W). Dots indicate the locations in which the visual surveys were carried out.

\section{Material and Methods}

\section{Study location}

Located between both the Atlantic Ocean and the Mediterranean Sea, the Strait of Gibraltar is an area of biogeographical interest and a biodiversity hotspot in Europe and the Mediterranean Sea [23]. Within the northern coast of the Strait of Gibraltar, El Estrecho Natural Park is a maritime-terrestrial protected area, created in 2003 and included in the Intercontinental Biosphere Reserve of the Mediterranean [24,25]. The marine segment of El Estrecho Natural Park includes a no-take/no-entry zone, which consists of a strip $0.8 \mathrm{~km}$ wide that extends $1.8 \mathrm{~km}$ along the southern coast of a small peninsula and a $1.8 \mathrm{~km}$ wide no-take zone with intermediate protection where non-invasive recreational activities are permitted (Figure 1).

\section{Data Collection and Treatment}

Surveys were conducted in September of year 2009 along the coast of the Island of Tarifa. Three sites were selected in the notake/no-entry zone of El Estrecho Natural Park MPA and three sites in a nearby non-protected area (see Figure 1). On each site, three transects $10 \mathrm{~m}$ long and $8 \mathrm{~m}$ wide were surveyed by a taxonomic expert using underwater visual censuses [26]. Data was collected on natural rocky bottoms at $8( \pm 2) \mathrm{m}$ depth within 9 and $11 \mathrm{~h}$ in the morning [27]. Fish species showing schooling behaviour were not considered. For the rest of species, all fishes present on the sea-bottom and water column were annotated. For highly abundant fishes, the number of encounters was estimated for each transect.

\section{Data Analyses}

Species abundance data was fourth root transformed and four resemblance matrixes were calculated in the basis of Bray-Curtis similarities, using (1) all species, (2) species with homing behaviour, (3) species of commercial interest and (4) species of commercial interest showing homing behaviour. Using these matrixes, nMDS ordinations and PERMANOVA and PERMDISP analyses were carried out, testing a nested design with factor Site (random, three levels) nested in Protection (fixed, two levels: protected and non-protected). Differences in fish abundances between protected and non-protected areas were tested using ANOVA and homogeneity of dispersions was tested using Levene's test. PRIMER-e v6 +PERMANOVA software was used for multivariate analyses and IBM SPSS Statistics 25 for univariate analyses [28].

\section{Results}

A total of 38 species belonging to 12 families were recorded (36 in the non-protected area and 28 in the no-take/no-entry area). Among them, Labridae and Sparidae were the most representative families in terms of species richness and abundance and Symphodus (Labridae) and Diplodus (Sparidae) the most abundant genera. Within the species recorded, species with homing behaviour (14) and of commercial interest were (29) the most abundant in terms of species richness and abundance on both protected and unprotected areas, although no differences in abundance were found between zones for any species group (Figure 2). Among species showing homing behaviour, ten species of commercial interest were found in the non-protected zone and seven in the protected zone. For those species, no differences in abun- 


\section{Oceanography \& Fisheries Open access Journal}

dance were found between protected and non-protected zones (P

es in community composition were found for any of the studied $($ Levene $)=0.192 ; \mathrm{P}(\mathrm{ANOVA})=0.425)$. Seemingly, no differencgroups of species (Figure 3).

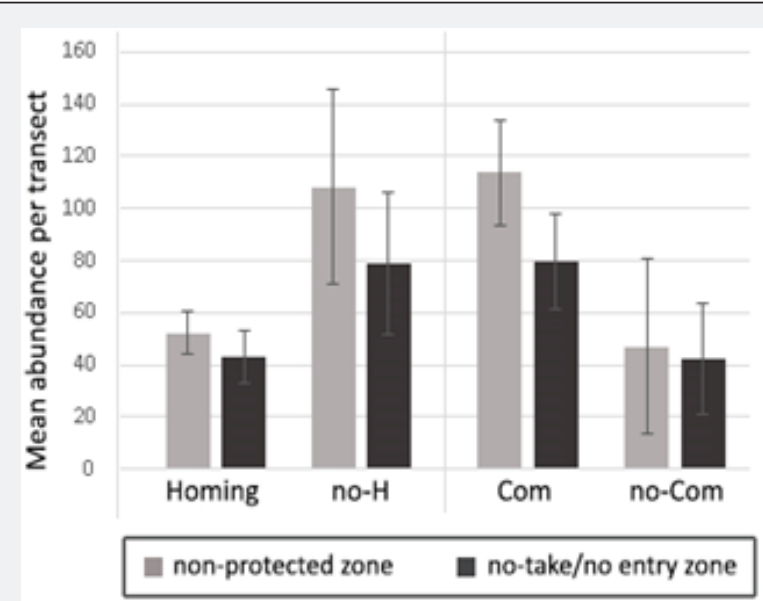

Figure 2: Mean abundance per transect and standard deviation error bars for the 38 fish species surveyed. Species were grouped attending to their homing behaviour and commercial interest. No differences in abundance were found between protected and unprotected zones for any of the species groups. Homing: species with homing behaviour (14); no-H: species without homing behaviour (25); Com: species of commercial interest (29); no-Com: species without commercial interest (9).

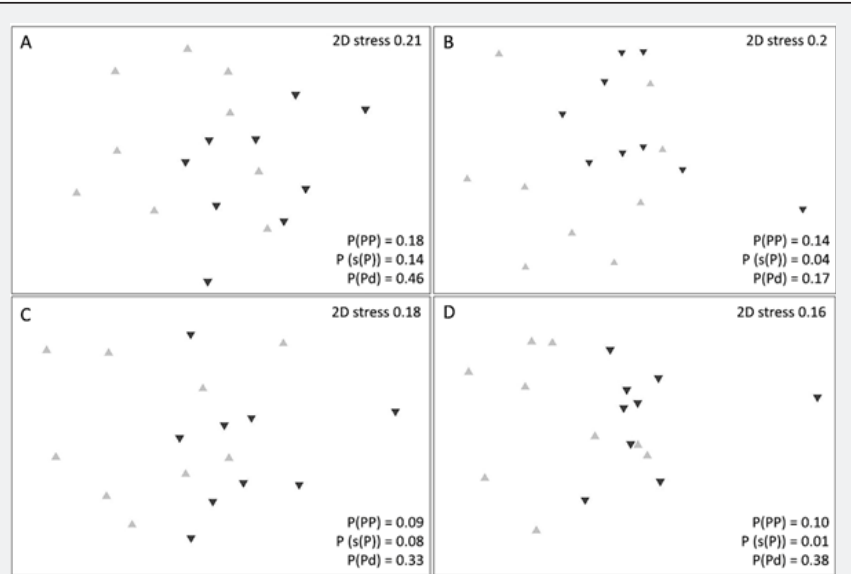

Figure 3: nMDS for (A) all species and the subsets: (B) species with homing behaviour, (C) species of commercial interest and (D) species with homing behaviour of commercial interest. Overall, no differences in community composition or multivariate dispersion were found between protected and non-protected zones, although differences occurred for some sites when using subsets $B$ and $D . P(P P)=P$ $(P E R M A N O V A)$ for factor Protection; $\mathrm{P}(\mathrm{s}(\mathrm{P}))=\mathrm{P}(\mathrm{PERMANOVA})$ for factor site (nested in Protection); $\mathrm{P}(\mathrm{Pd})=\mathrm{P}(\mathrm{PERMDISP})$ for factor Protection.

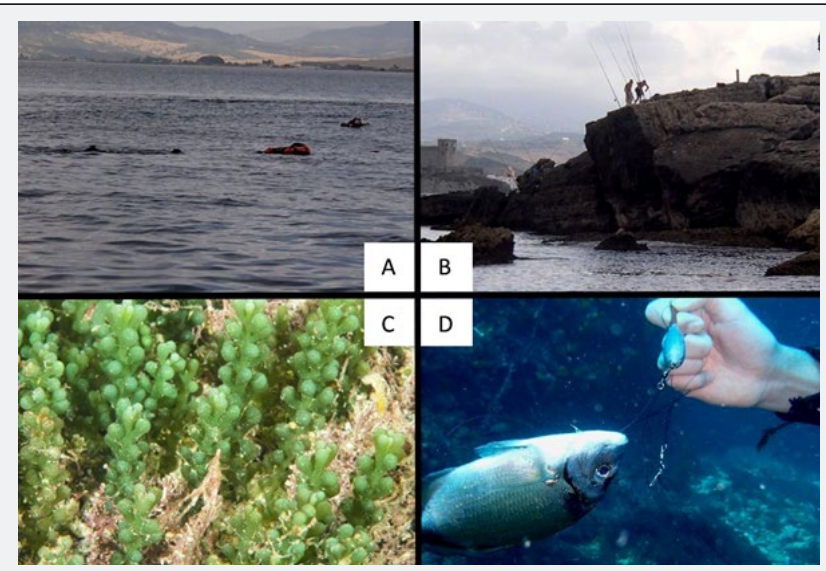

Figure 4: Observations on the no-take/no-entry zone of Tarifa Island in El Estrecho Natural Park. (A) illegal spear fishing activities, (B) illegal pole and line fishing, (C) invasive species Caulerpa cylindracea and (D) abandoned fishing equipment giving rise to ghost fishing. 


\section{Discussion}

Because of its size (less than $2 \mathrm{~km}^{2}$ ), the no-take/no-entry zone of Tarifa Island in El Estrecho Natural Park may have little to nonpositive effects on the conservation of fish populations, even for those showing low mobility or homing behaviour $[17,18$, 29]. Nevertheless, the results of this study may not invalidate the use of fish behavioural and economic interest indicators as tools for the monitoring of the reserve effect on this small MPA, as differences among protected and unprotected sites were bigger for these groups. Nonetheless, the absence of differences between zones may be a result of the low levels of protection and reinforcement in El Estrecho Natural Park, as those may be largely constrained by its annual economic assignations. In this matter, the mean economic assignation per hectare for national parks in Andalusia amounts to 23.4 euros, being human resources insufficient for an adequate reinforcement [30]. Hereby, recreational fishing is commonly observed in the study area, being spear fishers and pole and line fishers present in the no-take/no-entry zone all year round (Figure 4).

Therefore, it seems that protection could be unsuccessful in terms of fish communities in El Estrecho Natural Park. On the other hand, there are impacts to which MPAs cannot bring protection (such as those derived from climate change, biological invasions, marine litter and pollution) that may contribute to the homogenization of fish communities among protected and non-protected areas $[31,32]$. In this regard, the invasive seagrasses Caulerpa cylindracea (C in Figure 4), Asparagopsis armata, A. taxiformis and Rugulopteryx okamurae have been reported as pernicious species that could drive important changes in the trophic structure of the ecosystems [33-38]. Seemingly, marine litter such as lost fishing lines and nets could drive to fish mortalities both inside and outside the MPA (see D in Figure 4). Despite the differences in shoreline orientation, fish abundance and community composition patterns did not differ between protected and unprotected zones.

This suggests that the methodology carried out may be non-sensitive to environmental differences at small scales. Hereby, these indicators could be adequate to test possible protection effects on fish communities at the small Island of Tarifa no-take/ no-entry zone [39-42]. Nevertheless, differences among sites suggest that higher sampling effort may be needed for future studies carried out in this area, in order to properly represent the inherent variability of fish community in each zone [43]. It is concluded that the official establishment of the studied MPA should be further accompanied by genuine and effective protection measures, plus enough funding to ensure long-term protection. Considering the touristic attractive of Tarifa Island, an appropriate exploitation of touristic resources may be considered as a financial strategy that could increase reinforcement in El Estrecho Natural Park [44-50].

\section{Acknowledgment}

We would like to express our gratitude to Juan Corzo, Carlos María López, Aurora Ruíz and Roi González for their contributions to the study design and fieldwork. This study was supported by Autoridad Portuaria de la Bahía de Algeciras, Autoridad Portuaria de Sevilla and Aquagestión Sur (Acuario de Sevilla). We are also deeply grateful to the diving group from the Biology Faculty at the Universidad de Sevilla "CUASS" for helping and diving equipment during the study.

\section{References}

1. Gunette S, Lauck T, Clark C (1998) Marine reserves: From Beverton and Holt to the present. Reviews in Fish Biology and Fisheries 8(3): 251272.

2. Lester S E, Halpern B S, Grorud-Colvert K, Lubchenco J, Ruttenberg B I, et al. (2009) Biological effects within no-take marine reserves: a global synthesis. Marine Ecology Progress Series 384(2): 33-46.

3. Francour P (1994) Pluriannual analysis of the reserve effect on ichthyofauna in the Scandola Natural Reserve (Corsica, Northwestern Mediterranean). Oceanologica Acta 17(3): 309-317.

4. Russ G R, Alcala A C (1996) Do marine reserves export adult fish biomass? evidence from Apo Island, Central Philippines. Marine Ecology Progress Series 132(1-3): 1-9.

5. Bensenane M, Moussaoui A, Auger P (2013) On the optimal size of marine reserves. Acta Biotheor 61(1): 109-118.

6. Halpern BS, Lester SE and Kellner JB (2009) Spillover from marine reserves and the replenishment of fished stocks. Environmental Conservation 36(4): 268-276.

7. Goñi R, Badalamenti F, Tupper M H (2011) Fisheries-effects of marine protected areas on local fisheries: Evidence from empirical studies. Marine Protected Areas: A Multidisciplinary Approach 72.

8. Aswani S, Hamilton R (2004) The value of many small v. few large marine protected areas in the Western Solomon Islands. Traditional marine resource management and knowledge information bulletin 16 : 3-14.

9. Afonso P, Fontes J, Santos R S (2011) Small marine reserves can offer long term protection to an endangered fish. Biological Conservation 144(11): 2739-2744.

10. García-Gómez J C, Guerra-García J M, Espinosa F, Maestre M J, RiveraIngraham G, et al. (2014) Artificial Marine Micro-Reserves Networks (AMMRNs): an innovative approach to conserve marine littoral biodiversity and protect endangered species. Marine Ecology 36(3): 259-277.

11. Walters C (2000) Impacts of dispersal, ecological interactions, and fishing effort dynamics on efficacy of marine protected areas: how large should protected areas be? Bulletin of marine science 66(3): 745-757.

12. McNeill S, Fairweather P (1993) Single Large or Several Small Marine Reserves? An Experimental Approach with Seagrass Fauna. Journal of Biogeography 20(4): 429-440.

13. Rife A N, Erisman B, Sánchez A, Aburto-Oropeza O (2013) When good intentions are not enough...insights on networks of paper park marine protected areas. Conservation Letters 6(3): 200-212.

14. Brown C, Parker B, Ahmadia G N, Ardiwijaya R, Purwanto P, et al. (2017) The cost of enforcing marine protected areas to achieve ecological targets for the recovery of fish biomass. Biological Conservation 227: 259-265.

15. McManus, John W, Len R Garces, D Sadacharan (1998) A framework for future training in marine and coastal protected area management. WorldFish 57.

16. Botsford L W, Brumbaugh D R, Grimes C, Kellner J B, Largier J, et al. (2009) Connectivity, sustainability, and yield: bridging the gap 
between conventional fisheries management and marine protected areas. Reviews in Fish Biology and Fisheries 19(1): 69-95.

17. Nieder J (2001) Depth of sojourn and niche differentiation of benthic blennies (Pisces, Blenniidae) in the Mediterranean Sea (Catalonia, NE Spain and Italian coast of the Tyrrhenian Sea). Miscellania Zoologica 23(2): 21-33.

18. Azzurro E, La Mesa G, Fanelli E (2013) The rocky-reef fish assemblages of Malta and Lampedusa Islands (Strait of Sicily, Mediterranean Sea): A visual census study in a changing biogeographical sector. Journal of the Marine Biological Association of the United Kingdom 93(8): 20152026.

19. Abecasis D, Horta E Costa B, Afonso P, Goncalves E J, Erzini K (2015) Early reserve effects linked to small home ranges of a commercial fish, Diplodus Sargus, Sparidae. Marine Ecology Progress Series 518: 255266

20. Buelic I, Staglicic N, Lloret J, Matic-Skoko S (2015) Can restrictions in mediterranean artisanal fisheries be beneficial for target species? Acta Ichthyologica Et Piscatoria 45(1): 31-38.

21. Claudet J, Pelletier D, Jouvenel J Y, Bachet F, Galzin R (2006) Assessing the effects of marine protected area (MPA) on a reef fish assemblage in a northwestern Mediterranean marine reserve: Identifying communitybased indicators. Biological Conservation 130(3): 349-369.

22. Lamine E B, Di Franco A, Romdhane M S, Francour P (2018) Can citizen science contribute to fish assemblages monitoring in understudied areas? The case study of Tunisian marine protected areas. Estuarine, Coastal and Shelf Science 200: 420-427.

23. Coll M, Piroddi C, Steenbeek J, Kascher K, Ben Rais Lasram F, et al. (2010) The biodiversity of the Mediterranean Sea: estimates, patterns, and threats. PLoS One 5(8): e11842.

24. BOJA (2003) Decreto 57/2003 de 4 de marzo de declaración del Parque Natural del Estrecho. Boletín Oficial de la Junta de Andalucía, 54 Junta de Andalucía, Gobierno de España.

25. Malak D A, McGlade K, Pascual D, Pla E (2017) The Intercontinental Biosphere Reserve of the Mediterranean. Adapting to Climate Change 7-12.

26. Samoilys M A, Carlos G (2000) Determining methods of underwater visual census for estimating the abundance of coral reef fishes. Environmental Biology of Fishes 57(3): 289-304.

27. Willis T J, Badalamenti F, Milazzo M (2006) Diel variability in counts of reef fishes and its implications for monitoring. Journal of Experimental Marine Biology and Ecology 331(1): 108-120.

28. Anderson M J (2001) A new method for non-parametric multivariate analysis of variance. Austral Ecology 26(1): 32-46.

29. García-Gómez JC (2015) A guide of environmental monitoring of rocky seabeds in Mediterranean Marine Protected Areas and surrounding zones. In: Regional Activity Centre for Specially Protected Areas, RAC/ SPA, Tunisia, pp. 491.

30. Múgica GM, Martínez AC, Atauri MJA, Gómez-Limón JG, Puertas BJ, et al. (2017) Anuario 2016 del estado de las áreas protegidas en España. In: Fundación Interuniversitaria Fernando González Bernáldez para los espacios naturales. Europarc Federation, Madrid, España Pp. 135.

31. Alpert P, Bone E, Holzapfel C (2000) Invasiveness, invasibility and the role of environmental stress in the spread of non-native plants. Perspectives in Plant Ecology, Evolution and Systematics 3(1): 52-66.

32. Occhipinti Ambrogi A, Savini D (2003) Biological invasions as a component of global change in stressed marine ecosystems. Mar Pollut Bull 46(5): 542-551.

33. Piazzi L, Balestri E, Magri M, Cinelli F (1997) Expansion de l'algue tropicale Caulerpa racemosa (Forsskal) J Agardh (Bryopsidophyceae,
Chlorophyta) le long de la côte Toscane (Italie). Cryptogamie Algologie 18(4): 343-350

34. Pinnegar J K, Polunin N V C, Francour P, Badalamenti F, Chemello $\mathrm{R}$, et al. (2000) Trophic cascades in benthic marine ecosystems: Lessons for fisheries and protected-area management. Environmental Conservation 27(2): 179-200.

35. Altamirano Jeschke M, Román Muñoz A, De la Rosa J, Barrajón-Mínguez A, Barrajón-Menech A, et al. (2008) The invasive species Asparagopsis taxiformis (Bonnemaisoniales, Rhodophyta) on Andalusian coast (Southern Spain): reproductive stages, new records and invaded communities. Acta Botanica Malacitana 33: 5-15.

36. Baldacconi R, Corriero G (2009) Effects of the spread of the alga Caulerpa racemosa var. cylindracea on the sponge assemblage from coralligenous concretions of the Apulian coast (Ionian Sea, Italy). Marine Ecology 30(3): 337-345.

37. Sempere-Valverde J, Pellón G, Hocein B, Ostalé-Valriberas E, Espinosa F, et al. (2016) Observations and spread of the invasive algae Caulerpa cylindracea on the Strait of Gibraltar. Frontiers in Marine Science 186.

38. García-Gómez J C, Sempere-Valverde J, Ostalé-Valriberas E, Martínez M, Olaya-Ponzone L, et al. (2018) Rugulopterix okamurae (EY Dawson) I K Hwang, WJ Lee, HS Kim (Dictyotales, Ochrophyta), alga exótica "explosiva" en el estrecho de Gibraltar. Observaciones preliminares de su distribución e impacto. Almoraima 48: 97-113.

39. Harmelin J G, Bachet F, García F (1995) Mediterranean marine reserves: Fish indices as tests of protection efficiency. Marine Ecology 16(3): 233-250.

40. Westera M, Lavery P, Hyndes G (2003) Differences in recreationally targeted fishes between protected and fished areas of a coral reef marine park. Journal of Experimental Marine Biology and Ecology 294(2): 145-168

41. Amand M, Pelletier D, Ferraris J, Kulbicki M (2004) A step toward the definition of ecological indicators of the impact of fishing on the fish assemblage of the Abore reef reserve (New Caledonia). Aquatic Living Resources 17(2): 139-149.

42. Karnauskas M, Babcock E A (2014) An analysis of indicators for the detection of effects of marine reserve protection on fish communities. Ecological Indicators 46: 454-465.

43. Andrew N L, Mapstone B D (1987) Sampling and the description of spatial pattern in marine ecology. Oceanography and Marine Biology 25: 39-90.

44. Dharmaratne G S, Yee Sang F, Walling L J (2000) Tourism potentials for financing protected areas. Annals of Tourism Research 27(3): 590-610.

45. Milazzo M, Chemello R, Badalamenti F, Camarda R, Riggio S (2002) The impact of human recreational activities in marine protected areas: what lessons should be learnt in the Mediterranean sea? Marine ecology 23(s1): 280-290.

46. Fraschetti S, D Ambrosio P, Micheli F, Pizzolante F, Bussotti S, et al. (2009) Design of marine protected areas in a human-dominated seascape. Marine Ecology Progress Series 375: 13-24.

47. Bustamante G, Canals P, Di Carlo G, Gomei M, Romani M, et al. (2014) Marine protected areas management in the Caribbean and Mediterranean seas: making them more than paper parks. Aquatic Conservation: Marine and Freshwater Ecosystems 24(S2): 153-165.

48. Advani S, Rix L N, Aherne D M, Alwany M A, Bailey D M (2015) Distance from a fishing community explains fish abundance in a no-take zone with weak compliance. PLoS One 10(5).

49. BOJA (2007) Decreto 262/2007 de 16 de octubre por el que se aprueba el Plan Rector de Uso y Gestión del Parque Natural del Estrecho y se modifica el Plan de Ordenación de los Recursos Naturales del Frente 
Litoral Algeciras-Tarifa. Boletín Oficial de la Junta de Andalucía 233. Junta de Andalucía, Gobierno de España.
50. Torre PMD, Ruiz RF (2016) El turismo de buceo en la Isla de las Palomas, Tarifa. Facultad de Turismo y Finanzas, Universidad de Sevilla.

\section{Your next submission with Juniper Publishers} will reach you the below assets

- Quality Editorial service

- Swift Peer Review

- Reprints availability

- E-prints Service

- Manuscript Podcast for convenient understanding

- Global attainment for your research

- Manuscript accessibility in different formats

( Pdf, E-pub, Full Text, Audio)

- Unceasing customer service

Track the below URL for one-step submission https://juniperpublishers.com/online-submission.php 